\title{
PENGARUH LATIHAN LARI 12 MENIT DAN LARI BOLAK BALIK TERHADAP PENINGKATAN DAYA TAHAN VO2 $\max$
}

\author{
Anggi Yuga Prayuda ${ }^{1)}$, Guntur Firmansyah ${ }^{2)}$ \\ Pendidikan Jasmani Kesehatan dan Rekreasi \\ Fakultas Pendidikan Ilmu Eksakta dan KeolahragaanIKIP Budi Utomo \\ Email : 1yugaprayuda@gmail.com \\ 2 gunturpepeng@gmail.com
}

\begin{abstract}
ABSTRAK
Tujuan dari penelitian ini adalah untuk mengetahui pengaruh latihan lari 12 menit dan lari bolak balik terhadap peningkatan daya tahan VO2. Hasil data dari penelitian dianalisis dengan menggunakan teknik analisis varian satu jalur atau one way anova dengan taraf signifikansi 0,05. Dari uji tersebut diperoleh Fhitung sebesar 8,385<4,41 Ftabel pada hasil pretest dan posttest kelompok X1 dan diperoleh Fhitung sebesar 5,831<4,41 Ftabel pada hasil pretest dan posttest kelompok X1, kemudian untuk kelompok kontrol diperoleh Fhitung sebesar 0,00039< 4,41 dan untuk selisih kelompok X1 dengan kelompok kontrol diperoleh Fhitung sebesar 112,71 > 4,20 Ftabel dan selisih kelompok X2 dengan kelompok kontrol diperoleh Fhitung sebesar 73,14 > 4,20 Ftabel. Perolehan tersebut merujuk pada hasil penelitian yang diperoleh. Kesimpulan ada pengaruh signifikan antara latihan lari 12 menit dan lari bolak balik dengan latihan konvensional terhadap peningkatan daya tahan pemain.
\end{abstract}

Kata kunci: eksperimen, lari 12 menit, lari bolak-balik, daya tahan vo2 $\max$

\begin{abstract}
The purpose of this study was to determine the effect of running 12 minutes and running back and forth to increase VO2 endurance. The results of the data from the study were analyzed using one-way ANOVA variant analysis techniques with a significance level of 0.05 . From the test obtained Fcount of $8.338<4.41$ Ftable on the results of pretest and posttest in group X1 and obtained Fcount of $5.831<4.41$ Ftable on the results of the pretest and posttest group X1, then for the control group obtained Fcount of $0.00039<4,41$ and for the difference in group X1 with the control group obtained Fcount of 112.71> 4.20 Ftable and the difference in group X2 with the control group obtained Fcount of 73.14> 4.20 Ftable. The acquisition refers to the results of the research obtained. The conclusion is that there is a significant influence between running 12 minutes and running back and forth with conventional exercises to increase the player's endurance.
\end{abstract}

Keywords: experiment, 12 minutes run, shuttle run endurance vo2 $\max$ 


\section{PENDAHULUAN}

Untuk mencapai hidup yang sehat dapat dilakukan dengan berbagai cara, salah satunya adalah dengan melakukan aktivitas olahraga. Olahraga merupakan kegiatan yang sudah tidak asing di telinga setiap orang. Pada dasarnya setiap orang mempunyai kesempatan berolahraga sesuai yang diminati. Olahraga dapat di jadikan gaya hidup untuk setiap umat manusia. Olahraga terbukti dapat meningkatkan kesehatan dan tingkat kesegaran jasmani seseorang. Seseorang yang memiliki kesegaran jasmani prima dapat melakukan kegiatan sehari-hari dengan optimal dan tidak cepat lelah, serta masih memiliki cadangan energi untuk melakukan kegiatan lain. Kondisi tubuh yang kurang bagus di karenakan dari kurangnya berolahraga dapat mengakibatkan prestasi bekerja yang buruk terlihat dari daya tahan yang tidak memadahi. Dalam hal ini olahraga dapat di jadikan sebuah alat untuk memperbaiki dan mengembangkan kondisik fisik yang sering di butuhkan dalam kondisi tertekan ataupun tidak di duga.

Saat ini olahraga yang sangat banyak diminati oleh masyarakat indonesia adalah cabang olahraga futsal. Permainan futsal merupakan gabungan dari beberapa teknik individu dan tim yang menyatu dalam sebuah kerja sama keseluruhan. Pada dasarnya futsal adalah permainan yang sangat cepat dan dinamis. Permainan futsal yang dikenal dengan permainan cepat dan dinamis, dengan permainan seperti itu dibutuhkan daya tahan dan stamina yang cukup baik karena tanpa didukung dengan daya tahan dan stamina yang cukup kuat pola penyerangan dan pola pertahanan yang dibangun oleh sebuah tim tidak akan berjalan dengan baik.

Di Kota Malang, olahraga futsal adalah olahraga yang populer, seiring dengan perkembangan olahraga futsal di Indonesia, saat ini banyak sekali turnamen - turnamen baik itu antar pelajar, mahasiswa ataupun masyarakat umum. Dari situ banyak sekali rasa ketertarikan lebih besar terhadap olahraga futsal dengan banyaknya pelajar yang menggemari olaharaga tersebut. Hampir di setiap sekolah dapat di pastikan ada ekstrakulikuler futsal yang nantinya akan membentuk sebuah tim futsal untuk bisa eksis di turnamen futsal antar sekolah. Salah satunya adalah tim dari ekstrakulikuler futsal yang ada di SMK Negeri 6 Malang.

Menurut (Harsono,2015), "faktor yang mempengaruhi prestasi dan keterampilan seorang atlet adalah latihan. Latihan adalah proses yang sistematis dari berlatih yang dilakukan secara berulang-ulang, dengan kian Anggi Yuga Prayuda. Pengaruh Latihan Lari 12 Menit Dan Lari Bolak Balik Terhadap Peningkatan Daya Tahan Vo2 Max 
hari kian menambah jumlah beban latihan serta intensitas latihannya". (Mylsidayu dan Kurniawan, 2015) mengemukakan pendapatnya bahwa "latihan berasal dari kata dalam bahasa inggris yang dapat mengandung beberapa makna seperti: practice (praktek), exercise (latihan), dan training (latihan)."

Hal yang perlu di perhatikan adalah terjadinya peningkatan dalam latihan apabila latihan 12 dilakukan minimal 3x seminggu, dan maksimal 1214x dalam seminggu (sehari 2 sesi). Sebab, dalam keadaan normal, kelelahan yang timbul akan dapat diatasi dalam waktu antara 12-24 jam dan setelah itu atlet akan merasa segar dan bugar kembali (Harsono, 2015). Jadi, dapat di simpulkan bahwa peningkatan latihan terjadi secara signifikan apabila sekurang-kurangnya latihan $3 \mathrm{x}$ seminggu selama 4 minggu. Semakin sering/banyak latihan maka peningkatan akan terjadi semakin cepat, tetapi tetap harus memperhatikan prinsip-prinsip latihan agar tidak terjadi overtraining (latihan berlebih) menurut (Mylsidayu dan Kurniawan, 2015).

Menurut (Suhendro, dkk, 2007) "boredom (kebosanan) dalam dapat di kurangi atau dihilangkan dengan membuat olahraga tersebut menjadi menirik sehingga menimbulkan perhatian, rangsangan, dan motivasi bagi orang yang melakukan olahrag tersebut." Menururt (Harsono, 2015) menjelaskan "Latihan yang telalu berat yang melebihi kemampuan atlet untuk mampu menyesuaikan diri (adapt), apalagi tanpa ingat pentingnya istirahat, akan dapat mempengaruhi keseimbangan fisiologisnya, dan terlebih lagi psikologis atlet". Tingkat kecepatan atlet dalam mengadaptasi setiap beban latihan berbeda-beda tergantung dari usia/umur, usia latihan, kualitas latihan, kebugaran otot, kebugaran energi, dan kualitas latihannya (Sukadiyanto, 2015).

(Lhaksana, 2011) menyatakan bahwa "futsal adalah suatu permainan dengan menggunakan lapangan yang relatif lebih kecil dengan permainan yang sangat cepat dan dinamis diikuti dengan aturan yang lebih ketat. (Bangsbo dan Mohr, 2012) menjelaskan bahwa futsal is played between two teams of five players. the small size of the field and relative large number of players challenge improvisation, creativity and technique as well as ball control and passing in small spaces yang artinya futsal dimainkan oleh dua tim terdiri dari lima pemain, ukuran lapangan yang kecil dan sebagian besar pemain dituntut improvisasi, kreatif, teknik kontrol bola yang baik dan mengumpan di ruang yang kecil.

Anggi Yuga Prayuda. Pengaruh Latihan Lari 12 Menit Dan Lari Bolak Balik Terhadap Peningkatan Daya Tahan Vo2 Max 
(Amiq, 2014) menjelaskan bahwa "futsal banyak didominasi permainan kaki ke kaki, maksudnya pengaturan dalam bertahan maupun menyerang lebih banyak dilakukan dengan umpan-umpan pendek, mengingat ukuran lapangan yang lebih kecil dibanding lapangan sepakbola." Dari beberapa pendapat tersebut dapat ditarik kesimpulan bahwa futsal adalah suatu permainan yang dimainkan di area atau lapangan yang relatif lebih kecil dengan permainan cepat diikuti dengan peraturan yang ketat.

Menurut (Sugiharto, 2014), "VO2 max adalah jumlah maksimal oksigen yang dapat dikonsumsi selama aktivitas fisik yang intens sampai akhirnya terjadi kelelahan dan VO2 max dinyatakan dalam liter/menit/kilogram berat badan. VO2 maxini dapat membatasi kapasitas kardiovaskuler seseorang, maka VO2 maxdianggap sebagai indikator terbaik dari ketahanan aerobik". Menurut (Fenanlampir dan Muhyi, 2015)ada beberapa faktor yang mempengaruhi VO2 max sebagai berikut. 1) Jantung, paru dan pembuluh darah harus berfungsi dengan baik sehingga oksigen yang dihirup ke dalam paru selanjutnya sampai ke darah, 2) Proses penyampaian oksigen ke jaringan- jaringan sel-sel darah merah harus normal, yakni fungsi jantung harus normal, konsentrasi hemoglobin harus normal, jumlah sel darah merah harus normal dan pembuluh darah harus mampu mengalirkan darah dari jaringan-jaringan yang tidak aktif ke otot yang sedang aktif yang membutuhkan oksigen lebih besar, 3) Jaringanjaringan (terutama otot) harus mempunyai kapasitas yang normal untuk mempergunakan oksigen yang disampaikan kepadanya. Dengan kata lain, harus mempunyai metabolisme yang normal.

Berdasarkan pengamatan dan observasi penulis pada tanggal 29 Desember 2016, peserta ekstrakulikuler di SMK Negeri 6 Malang yang rata - rata berumur 16 - 17 tahun atau rata - rata kelas 10 dan 11, belum memiliki kemampuan fisik seperti Daya tahan cardiovesculer (VO2 max), ini terbukti saat melakukan pertandingan uji coba melawan tim futsal SMK Negeri 4 Malang. Jika pertandingan futsal biasanya 20 menit x 2 babak, namun pada saat uji coba melawan futsal SMK Negeri 4 Malang waktu yang diuji coba kan adalah 20menit x 3babak, dengan waktu yang cukup lama tersebut dibutuhkan stamina dan daya tahan tubuh yang baik, karena dalam permainan futsal diharuskan untuk bergerak secara terus menerus dalam keadaan menyerang ataupun bertahan. 


\section{METODE}

Penelitian ini termasuk jenis penelitian eksperimental yaitu penelitian yang menjelaskan perbandingan pengaruh antara sebelum diberi perlakuan dan sesudah diberikan perlakuan terhadap peningkatan daya tahan VO2 max siswa peserta ekstrakurikuler futsal. Adapun variabel yang diteliti meliputi variabel terikat berupa peningkatan kemampuan daya tahan VO2 max, dan variabel bebas berupa latihan lari 12 menit dan lari bolak-balik dan latihan gaya komando, sedangkan variabel kendalinya berupa jenis kelamin yaitu siswa laki-laki di ekstrakurikuler futsal usia 16-17 tahun.

Rancangan penelitian yang digunakan dalam penelitian ini adalah rancangan The Static Group Pre test-Post test Design. Penelitian ini menggunakan instrumen tes dan non tes, hasil keseluruhan tes digunakan untuk memperoleh data tes awal dan tes akhir variabel terikat berupa peningkatan kemampuan daya tahan VO2 max. Instrumen multistage fitness test ini dipilih karena pada umumya sering digunakan dalam menentukan daya tahan VO2 max seorang pemain. Sedangkan instrumen non tes berupa observasi digunakan untuk mengamati tes dan pelaksanaan perlakuan. Tes awal bertujuan untuk mengukur kemampuan awal, setelah mengambil data tes awal maka selanjutnya melaksanakan latihan lari 12 menit dan latihan lari bolak-balik selama 6 minggu.

Rancangan The Static Group Pre test-Post test Design

\begin{tabular}{lccc}
\hline Kelompok & Pretest & Perlakuan & Posttest \\
\hline $\mathrm{A}$ & $\mathrm{O}_{1}$ & $\mathrm{X}_{1}$ & $\mathrm{O}_{2}$ \\
\hline $\mathrm{B}$ & $\mathrm{O}_{1}$ & $\mathrm{X}_{2}$ & $\mathrm{O}_{2}$ \\
\hline $\mathrm{C}$ & $\mathrm{O}_{1}$ & $\mathrm{X}_{3}$ & $\mathrm{O}_{2}$
\end{tabular}

\section{(Sumber: Sukmadinata, 2013:209)}

Teknik analisis data yang digunakan dalam penelitian ini adalah analisis varian satu jalur (one way anova) yaitu untuk menguji perbedaan dua mean distribusi atau lebih. Uji normalitas adalah uji yang dilakukan untuk mengecek apakah data kita berasal dari populasi yang sebenarnya normal. Untuk menguji normalitas data digunakan uji lilliefors (Sudjana, 2005). Menurut (Sugiyono, 2011), "pengujian homogen diperlukan sebelum analisis varians dilakukan, pengujian dilakukan dengn menggunakan uji F”. 


\section{HASIL DAN PEMBAHASAN}

Berdasarkan hasil analisis varian satu jalur tes awal dan tes akhir multistage yang dilakukan pada kelompok lari 12 menit (X1), diperoleh kesimpulan bahwa ada pengaruh yang signifikan terhadap peningkatan daya tahan vo2 max pemain. Kesimpulan Berdasarkan hasil uji hipotesis yang menggunakan alnalisis varian satu jalur pada kelompok lari 12 menit (X1) diperoleh Fhitung sebesar 8,385 > dari Ftabel dengan taraf signifikansi $\alpha$ $0.05=4,41$, sehingga hipotesis nihil ditolak. Kesimpulan tersebut diperoleh berdasarkan beberapa aspek yang cukup terpenuhi dalam pelaksanaan latihan lari 12 menit yaitu, stamina tubuh para pemain yang mengalami perubahan oleh berbagai kondisi, pola istirahat yang dilakukan secara teratur dan masa pemulihan yang cukup setelah melakukan berbagai aktivitas diluar jam latihan. Stamina atau kondisi fisik yang baik diperlukan untuk program latihan maupun pertandingan, yang mempengaruhi seluruh aspek latihan. Stamina yang baik akan memengaruhi kondisi fisik pemain saat mengikuti proses latihan.

Tabel 1. Hasil Analisis Varians Skor Prestasi Kelompok Latihan Lari 12 menit (X1)

\begin{tabular}{lllllll}
\hline SV & Dk & JK & V & F $_{\text {hitung }}$ & $\mathbf{F}_{\text {tabel }}$ & Keputusan \\
\hline T & $20-1=19$ & 310,152 & - & & & $F_{\text {hitung }}>F_{\text {tabel }}$ \\
A & $2-1=1$ & 98,568 & 98,568 & 8,385 & 4,41 & $(8,385$ \\
D & $30-2=28$ & 211,584 & 11,7547 & & & $4,41)$ \\
\hline
\end{tabular}

Berdasarkan penjelasan tersebut maka sangat penting kondisi fisik pemain yang optimal, hal tersebut memengaruhi keaktifan pemain dalam mengikuti berbagai tahapan dan proses selama latihan, sehingga mempengaruhi pula peningkatan daya tahan yang dimiliki.

Berdasarkan hasil analisis varian satu jalur tes awal dan tes akhir multistage yang dilakukan pada kelompok lari bolak balik (X2), diperoleh kesimpulan bahwa ada pengaruh yang signifikan terhadap peningkatan daya tahan vo2 max pemain. Kesimpulan Berdasarkan hasil uji hipotesis yang menggunakan alnalisis varian satu jalur pada kelompok lari bolak balik (X2) diperoleh Fhitung sebesar 5,831> dari Ftabel dengan taraf signifikansi $\alpha$ $0.05=4,41$, sehingga hipotesis nihil ditolak. Kesimpulan tersebut diperoleh 
berdasarkan beberapa aspek yang cukup terpenuhi dalam pelaksanaan latihan lari bolak balik yaitu, stamina tubuh para pemain yang mengalami perubahan oleh berbagai kondisi, pola istirahat yang dilakukan secara teratur dan masa pemulihan yang cukup setelah melakukan begbagai aktivitas diluar jam latihan. Stamina atau kondisi fisik yang baik diperlukan untuk program latihan maupun pertandingan, yang mempengaruhi seluruh aspek latihan. Stamina yang baik akan memengaruhi kondisi fisik pemain saat mengikuti proses latihan.

Tabel 2. Hasil Analisis Varians Skor Prestasi Kelompok Latihan Lari Bolak Balik (X2)

\begin{tabular}{lllllll}
\hline SV & Dk & JK & V & F $_{\text {hitung }}$ & F tabel & Keputusan \\
\hline T & $20-1=19$ & 218,4875 & - & & & \\
A & $2-1=1$ & 53,4645 & 53,4645 & 5,831 & 4,41 & $\begin{array}{l}F_{\text {hitung }}>F_{\text {tabel }} \\
\text { D }\end{array}$ \\
\hline
\end{tabular}

Berdasarkan penjelasan tersebut maka sangat penting kondisi fisik pemain yang optimal, hal tersebut memengaruhi keaktifan pemain dalam mengikuti berbagai tahapan dan proses selama latihan, sehingga mempengaruhi pula peningkatan daya tahan yang dimiliki.

Berdasarkan hasil uji hipotesis dengan analisis varian satu jalur antara lari 12 menit (X1 )dan lari bolak balik (X2) dengan latihan konvensional dalam peningkatan kemampuan daya tahan pemain. Latihan lari 12 menit (X1 )dan lari bolak balik (X2) memberikan pengaruhyang signifikan dari pada latihan konvensional (X3) yang dilakukan selama 6 minggu dengan 18 kali pertemuan dengan Fhitug > Ftabel sebesar 112,71 > 4,41 untuk latihan lari 12 menit (X1) dan Fhitug > Ftabel sebesar 73,14> 4,41 untuk latihan lari bolak balik (X2) dengan signifikansi $\alpha=0.05$ sehingga berada pada kesimpulan Hipotesis nihil ditolak. Hal ini dapat dibuktikan dengan adanya perbedaan peningkatan rata-rata (mean) yang didapatkan oleh masingmasing kelompok. Kelompok X1 dan X2 mengalami peningkatan (mean), yaitu sebesar 4,44 untuk kelompok X1 dan 3,27 untuk kelompok X2 sedangkan kelompok X3 hanya mengalami peningkatan (mean) sebesar 0,02. Sesuai dengan data yang diperoleh membuktikan bahwa latihan lari 12 dan 
lari bolak balik lebih baik dalam meningkatkan kemampuan daya tahan jika dibandingkan dengan latihan konvensional dan memberikan pengaruh yang signifikan terhadap kemampuan daya tahan pemain.

Tabel 3. Hasil Analisis Varians Selisih Skor Prestasi Tes Awal dengan Tes Akhir Masing-masing Kelompok

\begin{tabular}{lllllll}
\hline SV & Dk & JK & V & F $_{\text {hitung }}$ & $\mathbf{F}_{\text {tabel }}$ & Keputusan \\
\hline T & $30-1=29$ & 65,8095 & - & & & \\
A & $2-1=1$ & 52,8125 & 52,8125 & 73,14 & 4,41 & $\begin{array}{l}F_{\text {hitung }}<F_{\text {tabel }}( \\
\text { D }\end{array}$ \\
D & $30-2=28$ & 12,997 & 0,72206 & & & $>4,20)$
\end{tabular}

Berdasarkan penelitian yang telah dilakukan, latihan lari 12 menit dan lari bolak balik mampu memberikan pengaruh terhadap daya tahan pemain. Maka dari itu dapat di simpulkan bahwa kemampuan VO2 max seorang pemain begitu penting karena seperti yang di jelaskan oleh Sugiharto (2014:82) "VO2 max adalah jumlah maksimal oksigen yang dapat dikonsumsi selama aktivitas fisik yang intens sampai akhirnya terjadi kelelahan dan VO2 max dinyatakan dalam liter/menit/kilogram berat badan. VO2 max ini dapat membatasi kapasitas kardiovaskuler seseorang, maka VO2 max dianggap sebagai indikator terbaik dari ketahanan aerobik."

\section{SIMPULAN}

Hasil peneliitian yang dapat disimpulkan bahwa latihan lari 12 menit berpengaruh lebih baik dibandingkan latihan konvensional terhadap peningkatan daya tahan, latihan lari bolak balik berpengaruh lebih baik sama halnya seperti latihan lari 12 menit, dibandingkan dengan latihan konvensional terhadap peningkatan daya tahan latihan lari 12 menit dan lari bolak balik memberikan pengaruh yang signifikan dan berpengaruh lebih baik terhadap peningkatan daya tahan peserta ekstrakulikuler futsal usia 1617 tahun. Dengan memperhatikan hasil penelitian ini, maka dalam kesempatan ini penulis bermaksud ingin menyampaikan saran-saran sehubungan dengan harapan peneliti agar nantinya penelitian ini memiliki kemanfaatan yang sangat berarti bagi banyak pihak. Pelatih dapat menggunakan latihan lari 12 menit dan lari bolak balik sebagai bentuk 
latihan untuk meningkatkan daya tahan para pemain, Dalam penelitian selanjutnya hendaknya melihat tentang penelitian sebelumnya sehingga dalam menentukan atau melakukan penelitian sesuai dengan rancangan yang diinginkan

\section{DAFTAR PUSTAKA}

Amiq, Fahrial.2014.Futsal. Malang: UniversitasNegeri Malang.

Bangsbo,J,\& Mohr Magni (2012). Fitness Testing in Football- Fitness Training in Soccer II. www. Bangsbosport.com

Fenanlampir, Albertus \& Muhyi Faruq, M. 2015. Tes dan Pengukuran dalam Olahraga. Yogyakarta : CV Andi Offset.

Harsono. 2015. Teori dan Metodologi Kepelatihan Olahraga. Bandung : PT Remaja Rosdakarya.

Lhaksana, J. 2011. Taktik dan Strategi Futsal Modern. Jakarta: Be Champion.

Mylsidayu, Apta \& Kurniawan, Febi. 2015. Ilmu Kepelatihan Dasar. Surabaya : Pascasarjana Universitas Negeri Surabaya.

Sudjana. 2005.Metoda Statistika. Bandung : Tarsito.

Sugiharto. 2014.FisiologiOlahraga. Malang: UniversitasNegeri Malang.

Sugiyono. 2013. Metode penelitian pendidikan (pendekatankualitatif\&kuantitatif). Bandung: Alfabeta.

Suhendro, dkk. 2007. Buku Ajar Ilmu Penyakit Dalam. Jilid : 3. Ed : 4. Jakarta : Departemen Ilmu Penyakit Dalam FKUI.

Sukadiyanto. 2011.Pengantar Teori dan Metodologi Melatih Fisik. Bandung: Lubuk agung. 
Jp.jok (Jurnal Pendidikan. Jasmani, Olahraga dan Kesehatan)

Sukmadinata. 2013. Metode Penelitian Pendidikan . Bandung : PT Remaja Rosdakarya. 